\title{
Altered Gene Expression in Alzheimer's Disease Brain Tissue
}

\author{
Patrick C. May, Steven A. Johnson, Judes Poirier, Martha Lampert-Etchells \\ and Caleb E. Finch
}

\begin{abstract}
We review the evidence for altered gene expression in Alzheimer's disease brain and identify alternative molecular approaches for isolating additional novel markers. One marker, pADHC-9, was isolated from a human hippocampal cDNA library by differential screening with AD and control cDNA probes. This clone hybridizes to a $2 \mathrm{~Kb}$ RNA which is increased 2 fold in AD hippocampus. The deduced amino acid sequence of pADHC-9 codes for a 52 kDAL protein similar to a testicular sulfated glycoprotein secreted by rat Sertoli cells. The normal function of this protein in brain and whether that function is altered in Alzheimer's disease is unknown.

RÉSUMÉ: Modification de l'expression génique dans le tissu cérébral de patients atteints de la maladie d'Alzheimer Après une revue exhaustive des anomalies de l'expression génique relevées dans la maladie d'Alzheimer, nous décrivons une méthode qui nous a permis d'isoler de nouveaux marqueurs moléculaires. Un marqueur appelé pADHC-9 a été isolé, à partir d'une librairie d'ADN complémentraire provenant d'hippocampe humain, par hybridation différentielle avec des sondes d'ADN complémentaire provenant de patients atteints de la maladie d'Alzheimer et de sujets témoins. Ce clone montre une hybridation prononcée pour un ARN d'environ 2 kilobases dont la prévalence est augmentée d'au moins deux fois dans l'hippocampe de patients atteints de la maladie d'Alzheimer. Ce clone code pour un peptide de 52 kilodaltons dont la séquence en acides aminés suggère une forte homologie avec la glycoprotéine testiculaire sulfatée secrétée par les cellules de Sertoli du rat. La fonction normale de cette protéikne dans le cerveau et son rôle dans la maladie d'Alzheimer demeurent jusqu'à présent inconnus.
\end{abstract}

Can. J. Neurol. Sci. 1989; 16:473-476

During Alzheimer's disease (AD), the entorhinal/hippocampal/subicular pathway undergoes both specific neuronal degeneration and some aspects of neuronal regeneration. Deficits in hippocampal function due to intrinsic neuron loss, particularly in $\mathrm{CA} 1$ and subiculum ${ }^{1}$ are compounded by degeneration of entorhinal cortical neurons projecting to the hippocampus via the perforant pathway. 2,3 This "functional deafferentation" of the AD hippocampus elicits sprouting and reactive synaptogenesis which resembles that observed in the hippocampus of rodents following experimental perforant path lesion.4,5 Regenerative events are not limited to the hippocampus but also occur in the entorhinal cortex as evidenced by the sprouting of collateral axons from pyramidal neurons. ${ }^{6}$

It is likely that selective changes in hippocampal gene expression accompany the neuropathology in AD even in "nonfamilial" cases; these changes may even participate in the neurodegenerative mechanism. Although the molecular mechanisms responsible for sprouting and synaptic remodelling are unknown, 4,6 they are likely to require increased transcription of growth and survival factors. ${ }^{7}$ By cloning hippocampal RNA sequences altered in $A D$, novel sequences associated with neurodegeneration and regeneration may be identified.

\section{Evidence for Altered Gene Expression in AD}

Several laboratories have characterized RNA from postmortem human brain. Some reports on RNA preparations from brains with conventional post-mortem delays indicate considerably lower yields of total $\mathrm{RNA}^{8,9}$ or polyadenylated [poly(A)]RNA 10 from AD than control cerebral cortex. However, recent work from our laboratory and others indicates that comparable levels of total and poly(A)RNA can be extracted from $A D$ and control hippocampus 11,12 and cerebral cortex. 13,14

Little is known about the specificity of changes in gene expression in AD hippocampus. Cytologic studies indicate consistent decreases in pyramidal neuron total RNA content and nucleolar shrinkage in AD hippocampus, a parameter which primarily reflects changes in ribosomal RNA content. ${ }^{15-18}$ In contrast to the decrease in bulk RNA content, which may simply reflect neuronal atrophy, two markers of $\mathrm{AD}$ (A68 protein and beta-amyloid peptide) may increase in specific neuron populations and represent selective alterations in hippocampal gene expression.

\section{Specific Markers for Altered Gene Expression in AD}

The A68 protein, recognized by the Alz-50 monoclonal antibody, is expressed predominantly in degenerating neurons in AD hippocampus, temporal cortex and nucleus basalis. 19 Although tangle-bearing neurons react strongly, some tanglefree neurons also express the Alz-50 epitope. 19.20 While dynamic interpretations of static data are appropriately subject to criticism, Alz-50 positive, tangle-free neurons tend to be localized 
to the same neuronal populations that are at risk in $A D,{ }^{20}$ suggesting that alterations in gene expression may precede neuronal degeneration. In addition, cytospectrophotometric analysis of Alz-50-positive neurons in the hippocampus indicates decreased RNA content compared with neighboring Alz-50-negative neurons. ${ }^{21}$ Interestingly, the epitope recognized by Alz-50 appears to be developmentally regulated, as it is also expressed in neurons of late fetal and neonatal human brain tissue. ${ }^{22}$ The aberrant re-expression of this epitope (or protein) in AD may reflect and/or result in neuronal dysfunction.

Similarly the marked deposition of beta-amyloid-peptide containing plaques in the AD hippocampal formation may stem from selective changes in hippocampal gene expression. Betaamyloid precursor protein (APP) mRNA is expressed in neurons throughout the hippocampal formation. ${ }^{23}$ The prevalence of APP mRNA is typically three fold higher in CA3 than parasubiculum in the normal hippocampus; this differential expression of APP mRNA was not observed in AD. ${ }^{24}$ Higgins and colleagues ${ }^{24}$ argue that the change in APP mRNA prevalence is due to an increased expression in affected parasubicular neurons rather than decreased expression or loss of CA3 pyramidal neurons. The identification of alternative spliced forms of APP mRNA $25-27$ complicates the interpretation of this result since the APP cRNA probe used in the early study recognizes all forms of APP mRNA. Nevertheless, these findings suggest that some change in beta-amyloid gene expression may occur in selected neurons at risk in $A D$ hippocampus. The increased levels of APP message in AD nucleus basalis neurons ${ }^{28}$ are consistent with this suggestion; however, the disparity between relative plaque density and neurons expressing APP message in neocortex of AD patients argues against a simple causal relationship between overexpression of APP message and neuropathology. ${ }^{29}$

\section{Approaches to Identifying Altered Gene Expression in}

\section{Alzheimer's Disease}

The paucity of information concerning altered gene expression in $\mathrm{AD}$ underscores the need for additional markers of selective changes in hippocampal gene expression in AD. Many investigators have screened brain cDNA expression libraries with antibodies against proteins known to be altered in AD; cDNA clones for human alpha- 1 antichymotrypsin, 30 beta-amyloid precursor protein, ${ }^{31}$ glial fibrillary acidic protein (GFAP), ${ }^{32}$ microtubule associated protein-2 (Map-2) ${ }^{33}$ and Tau ${ }^{34}$ have been obtained by this method. A different approach, used successfully by Miller and colleagues, ${ }^{35}$ is to screen $\mathrm{AD}$ and control brain tissue sections with monoclonal antibodies to unknown proteins (but related to epitopes expressed in Drosophila head). Monoclonal antibodies that recognize epitopes altered in AD can then be used to screen brain cDNA expression libraries to isolate novel cDNA clones. In a third approach, we have cloned brain RNA transcripts with altered prevalence in AD by differential hybridization screening of a human hippocampal cDNA library. This manuscript will summarize the results obtained to date; detailed information will be published elsewhere.

\section{Construction and Screening of an AD/Control Hippocampal cDNA Library}

Total RNA was extracted from frozen post-mortem hippocampus and poly(A)RNA isolated by oligo-d(T) cellulose chromatography. Comparable yields of total and poly(A)RNA were obtained from AD (382 \pm 24 ug RNA/g tissue, $1.1 \%$ poly(A); $n=9$ ) and control (334 \pm 32 ug RNA/g tissue, $1.1 \%$ poly(A); $n=11$ ) hippocampus. Double stranded cDNA was synthesized from poly(A)RNA pooled from $\operatorname{AD}(n=4)$ and control (CTL) $(n=6)$ subjects and cloned into lambda gt- 10 by conventional techniques. Approximately 50,000 recombinants from the mixed AD and CTL hippocampal CDNA library were screened by differential hybridization to AD or CTL-cDNA probes. Sixty-one plaques which gave a differential signal of two-fold or greater were picked for study. Further examination of 23 clones by secondary and tertiary screening revealed 11 clones which consistently showed a 2 to 5 -fold prevalence increase in AD compared to CTL hippocampus. Non-changing clones used for hybridization controls expressed differential signals averaging $0.9 \pm 0.1$ (mean \pm SEM, $n=5$ ). The 11 AD-related cDNA clones fall into two groups as determined by cross hybridization analyses.

\section{Human Glial Fibrillary Acidic Protein cDNA}

Nine clones, belonging to one group of AD-related cDNAs, hybridized to a $3.3 \mathrm{~Kb}$ RNA whose prevalence was increased two-fold or more in the hippocampus and in cortical regions with prominent neurodegeneration in $\mathrm{AD}$. Nucleotide sequence analysis indicated this class represented multiple independent cloning of human GFAP. The increase in GFAP mRNA is expected in view of the extensive astrocytosis found during AD. Even so, the constancy of GFAP mRNA levels in the cerebellum, a region spared in $A D$, indicates the regional specificity of this change.

\section{pADHC-9}

A second group of AD-related clones, designated pADHC-9, hybridized to a $2 \mathrm{~Kb}$ RNA whose prevalence was increased two fold in AD hippocampus but not in most cortical regions. In situ hybridization analyses indicated pADHC-9 has a laminar distribution in the entorhinal cortex and hippocampus. Prominent labelling was observed in pyramidal cells as well as in a subset of cells bordering the hilar side of the dentate gyrus granule cell layer. ${ }^{36}$ Sequencing of pADHC-9 identified an open reading frame of 449 amino acid residues coding for a putative $52 \mathrm{kDal}$ protein. ${ }^{37}$ The deduced protein includes a presumptive signal peptide sequence, 6 presumptive asparagine-linked glycosylation sites as well as 2 possible attachment sites for glycosaminoglycans. The nucleotide and deduced amino acid sequence of this protein share $75-80 \%$ identity to rat sulfated glycoprotein 2 , the major secretory product of Sertoli cells in the testes. ${ }^{38}$ In addition to the consensus signal peptide and presumptive asparagine-linked glycosylation sites mentioned above, a proteolytic cleavage site and 10 cysteine residues are conserved between these two proteins. These data suggest that pADHC-9 may encode a highly processed glycoprotein related and possibly identical to a human homolog for rat sulfated glycoprotein-2. The function of this protein in brain and its possible dysfunction in $\mathrm{AD}$ is unknown.

\section{Entorhinal Cortex Lesions as a Model for AD Hippocampal Pathology}

To analyze further the causes of altered prevalence of hippocampal transcripts in $\mathrm{AD}$, we are using rats with entorhinal cortex lesions to model select aspects of the neurodegeneration 
and regeneration occurring in AD. Geddes et al ${ }^{4}$ showed that sprouting responses in the dentate gyrus during $A D$ were remarkably similar to those induced in entorhinal cortexlesioned rats. To examine molecular changes associated with denervation of the hippocampus, Northern blot and solution hybridization analyses were conducted with total RNA extracted from deafferented and intact rat hippocampus. As observed in AD hippocampus, GFAP mRNA was elevated several fold in hippocampal RNA from entorhinal cortex lesioned rats. ${ }^{39}$ In situ hybridization analyses, using ${ }^{35}$ S-GFAP cRNA probes, localized the increased expression of GFAP mRNA to the outer $2 / 3$ of the molecular layer of the dentate gyrus where projections from the entorhinal cortex terminate. ${ }^{39}$ These results with GFAP encourage our use of this model system to characterize the expression of pADHC-9 and its possible role in neurodegeneration or regeneration.

\section{SUMMARY}

Select changes in hippocampal gene expression occur in Alzheimer's disease. A number of investigators are focusing on the regulation and function of the beta-amyloid precursor protein, given the accumulation of its breakdown product in amyloid plaques within the brain parenchyma and cerebral vasculature. However, it is likely that changes in other hippocampal RNA transcripts accompany the neuropathology in $A D$ and may even participate in the neurodegenerative and regenerative events occurring during the course of the disease. We have identified a novel hippocampal poly(A)RNA sequence which is elevated in AD hippocampus. The polypeptide encoded by this RNA is similar to a proteolytically processed, secreted sulfated glycoprotein previously characterized in the rat testes where it presumably participates in spermatogenesis. The normal function of this protein in brain and whether its regulation is altered in $A D$ is unknown. However, given the recent data indicating secreted forms of processed amyloid precursor protein, 40 it is tempting to speculate that future studies on pADHC-9 will reveal impaired processing of another secreted glycoprotein in AD brain.

\section{ACKNOWLEDGEMENTS}

We would like to acknowledge Heinz Osterburg, Sharon Millar and Chris Anderson for their expert technical assistance. This research was supported by ADRDA Grant IIRG-88-069 (PCM), ADRDA Research Grant (SAJ), the Le Fond de la Récherche en Santé du Québec (JP), ADRC Grant \#AG05142 and the John D. and Catherine T. MacArthur Foundation Research Program on Successful Aging (CEF).

\section{Note Added in Proof:}

We have recently shown that the ratio of APP 751 to APP 695 RNA prevalence increases in AD hippocampus and AD cortex but not in $A D$ cerebellum as judged by RNA blots of poly(A)RNA ${ }^{41}$ or by in situ hybridization analyses of hippocampal sections (Johnson et al., in prep).

\section{REFERENCES}

1. Ball MJ, Hachinski V, Fox A, et al. A new definition of Alzheimer's disease: a hippocampal dementia. Lancet 1985; 1: 14-16.

2. Hyman BT, Van Hoesen GW, Damasio AR, et al. Cell specific pathology isolates the hippocampal formation. Science 1984; 225: $1168-1170$.
3. Hyman BT, Van Hoesen GW, Kromer LJ, et al. Perforant pathway changes and the memory impairment of Alzheimer's disease. Ann Neurol 1986; 20: 472-481.

4. Geddes JW, Monaghan DT, Cotman CW, et al. Plasticity of hippocampal circuitry in Alzheimer's disease. Science 1985; 230: 1179-1181.

5. Hyman BT, Kromer LJ, Van Hoesen GW. Reinnervation of the hippocampal perforant pathway zone in Alzheimer's disease. Ann Neurol 1987; 21: 259-267.

6. Probst A, Basler V, Bron B, et al. Neuritic plaques in senile dementia of Alzheimer type: a Golgi analysis in the hippocampal region. Brain Res 1983; 268: 249-254.

7. Cotman CW, Nieto-Sampedro M. Reactive synaptogenesis in the hippocampus. Science 1985; 225: 1287-1294.

8. Sajdel-Sulkowska EM, Marotta CA. Alzheimer's disease brain alterations in RNA levels and a ribonuclease-inhibitor complex. Science 1984; 225: 947-949.

9. Taylor GR, Carter GI, Crow TJ, et al. Measurement of relative concentrations of RNA in postmortem brains from senile dementia of the Alzheimer type (SDAT) and controls. J Neurogenet 1985; 2: 177.

10. Guillemette JG, Wong L, Crapper-McLachlan DR, et al. Characterization of messenger RNA from the cerebral cortex of control and Alzheimer-afflicted brain. J Neurochem 1986; 47: 987-997.

11. May PC, Johnson SA, Masters JN, et al. Cloning of poly(A)RNA differentially regulated in Alzheimer's disease from a hippocampal cDNA library. Soc Neurosci Abs 1987; 13: 1325.

12. Wallace W, Winblad B. Progress towards a molecular genetic approach to Alzheimer's disease. Neuro-psychopharmacol Biol Psychiat 1986; 10: 657-663.

13. Johnson SA, Morgan DG, Finch CE. Extensive postmortem stability of RNA from rat and human brain. J Neurosci Res 1986; 16: $272-280$.

14. Morrison MR, Pardue S, Maschoff $\mathrm{K}$, et al. Brain messenger RINA and ribonuclease activity in Alzheimer's disease. Biochem Soc Trans 1986; 15: 133-134.

15. Doebler JA, Markesbery WR, Anthony A, et al. Neuronal RNA in relation to Alz-50 immunoreactivity in Alzheimer's disease. Ann Neurol 1988; 23: 20-24.

16. Mann DMA. The neuropathology of Alzheimer's disease: a review with pathogenetic, aetiological and therapeutic considerations. Mech Ageing Devel 1985; 31: 213-255.

17. Mann DMA, Neary D, Yates PO, et al. Neurofibrillary pathology and protein synthetic capability in nerve cells in Alzheimer's disease. Neuropathol Appl Neurobiol 1981; 7: 37-47.

18. Mann DMA, Neary D, Yates PO, et al. Alterations in protein synthetic capability in nerve cells in Alzheimer's disease. J Neurol Neurosurg Psychiatry 1981; 44: 97-102.

19. Wolozin BL, Pruchnicki A, Dickson DW, et al. A neuronal antigen in the brains of Alzheimer patients. Science 1986; 232: 648-652.

20. Hyman BT, Van Hoesen GW, Wolozin BL, et al. Alz-50 antibody recognizes Alzheimer-related neuronal changes. Ann Neurol 1988; 23: 371-379.

21. Doebler JA, Markesbery WR, Anthony A, et al. Neuronal RNA in relation to neuronal loss and neurofibrillary degeneration in Alzheimer diseased hippocampus. J Neuropath Exp Neurol 1987; 466: 28-29.

22. Wolozin BL, Scicutella A, Davies P. Reexpression of a developmentally regulated antigen in Down syndrome and Alzheimer disease. Proc Natl Acad Sci USA 1988; 85: 6202-6206.

23. Bahmanyar S, Higgins GA, Goldgaber D, et al. Localization of amyloid beta protein messenger RNA in brains from patients with Alzheimer's disease. Science 1987; 237: 77-80.

24. Higgins GA, Lewis DA, Young WG, et al. Differential regulation of amyloid-B-protein mRNA expression within hippocampa! neuronal subpopulations in Alzheimer disease. Proc Natl Acad Sci USA 1988; 85: 1297-1301.

25. Kitaguchi N, Takahashi Y, Tokushima Y, et al. Novel precursor of Alzheimer's disease amyloid A4 protein shows protease inhibitory activity. Nature $1988 ; 331$ : 530-532. 
26. Ponte P, Gonzalez-DeWhitt J, Schilling J, et al. A new A4 amyloid mRNA contains a domain homologous to serine proteinase inhibitors. Nature 1988; 331: 525-527.

27. Tanzi RE, McClatchey AI, Lamperti EG, et al. Protease inhibitor domain encoded by an amyloid protein precursor mRNA associated with Alzheimer's disease. Nature 1988; 331: 528-530.

28. Cohen ML, Golde TE, Usiak MF, et al. In situ hybridization of nucleus basalis neurons shows increased B-amyloid mRNA in Alzheimer disease. Proc Natl Acad Sci USA 1988; 85: 12271232.

29. Lewis DA, Higgins GA, Young WG, et al. Distribution of precursor amyloid- $\$$-messenger RNA in human cerebral cortex. Proc Natl Acad Sci USA 1988; 85: 1691-1695.

30. Abraham CR, Selkoe DL, Potter H. Immunochemical identification of the serine protease inhibitor alpha-1-antichymotrypsin in the brain amyloid deposits of Alzheimer's disease. Cell 1988; 52: 487-501.

31. Zain SZ, Salim M, Chou W-G, et al. Molecular cloning of amyloid cDNA derived from mRNA of the Alzheimer Disease brain: coding and noncoding regions of the fetal mRNA are expressed in the cortex. Proc Natl Acad Sci USA 1988; 85: 929-933.

32. Salim M, Rehman S, Sajdel-Sukowska EM, et al. Preparation of a recombinant $c D N A$ library from poly $(A+) R N A$ of the Alzheimer brain. Identification and characterization of a cDNA copy encoding a glial-specific protein. Neurobiol Aging 1988; 9: 163-171.

33. Dammerman $M$, Goldstein $M$, Yen S-HC, et al. Isolation and characterization of cDNA clones encoding epitopes shared with Alzheimer neurofibrillary tangles. J Neurosci Res 1988; 19: 4351.

34. Goedert M, Wischik CM, Crowther RA, et al. Cloning and sequencing of the cDNA encoding a core protein of the paired helical filament of Alzheimer disease: identification as the microtubule-associated protein tau. Proc Natl Acad Sci USA 1988; 85: 4051-4055.

35. Miller CA, Rudnicka M, Hinton DR, et al. Monoclonal antibody identification of subpopulations of cerebral cortical neurons affected in Alzheimer disease. Proc Natl Acad Sci USA 1987; 84: 8657-8661.

36. May PC, Johnson SA, Lampert-Etchells MA, et al. In situ mapping of pADHC-9: a poly(A)RNA sequence overexpressed in Alzheimer's disease hippocampus. Soc Neurosci Abs 1988; 14: 897.

37. May PC, Lampert-Etchells MA, Anderson CP, et al. The Alzheimer's related hippocampal cDNA clone pADHC-9 encodes a $52 \mathrm{kDAL}$ protein similar to a rat testicular sulfated glycoprotein. Soc Neurosci Abs (in press).

38. Collard MW, Griswold MD. Biosynthesis and molecular cloning of sulfated glycoprotein 2 secreted by rat sertoli cells. Biochemistry 1987; 26: 3297-3303.

39. Poirier J, May PC, Finch CE. Alteration in glial fibrillary acidic protein mRNA content in the rat hippocampus after entorhinal cortex lesion. Soc Neurosci Abs 1987; 14: 897.

40. Weidemann A, Konig G, Bunke D. Identification, biogenesis and localization of precursors of Alzheimer's disease A4 amyloid protein. Cell 1989; 57: 115-126.

41. Johnson SA, Rogers J and Finch CE. APP-695 transcript prevalence is selectively reduced during Alzheimer's disease in cortex, hippocampus but not in cerebellum. Neurobiol Aging 1989; 10: $267-272$. 